\title{
Latest Pleistocene lake shorelines and glacial chronology in the Western Basin and Range Province, U.S.A.: insights from AMS radiocarbon dating of rock varnish and paleoclimatic implications
}

\author{
Ronald I. Dorn ${ }^{1}$, A. J. T. Jull ${ }^{2}$, D. J. Donahue ${ }^{2}$, T. W. Linick ${ }^{2}$, and L. J. Toolin ${ }^{2}$ \\ ${ }^{1}$ Geography Department, Arizona State University, Tempe, AZ 85287-0104 (U.S.A.) \\ ${ }^{2}$ NSF Regional Facility of Radioisotope Analysis, University of Arizona, Tucson, AZ 85721 (U.S.A.)
}

(Received May 15, 1989; accepted August 15, 1989)

\begin{abstract}
Dorn, R. I., Jull, A. J. T., Donahue, D. J., Linick, T. W. and Toolin, L. J., 1990. Latest Pleistocene lake shorelines and glacial chronology in the Western Basin and Range Province, U.S.A.: insights from AMS radiocarbon dating of rock varnish and paleoclimatic implications. Palaeogeogr., Palaeoclimatol., Palaeoecol., 78: 315-331.

Accelerator mass spectrometry radiocarbon dating of organic matter in the basal layer of rock varnish provides a minimum surface exposure age for the underlying landform. Varnishes ${ }^{14} \mathrm{C}$ ages indicate that the latest Pleistocene highstand of Lake Lahontan was abandoned before $12.7 \mathrm{ka}$, Searles Lake before $13.6 \mathrm{ka}$, Lake Manly before $13.0 \mathrm{ka}$, and Lake Mojave before 11.6 ka. The maxima of the Tioga glaciation at Pine Creek in the eastern Sierra Nevada, California, and the Middle Creek glaciation in the adjacent White Mountains of California-Nevada was just before 18-19 ka; major recessional moraines were deposited in these ranges before 12-13 ka. Penecontemporaneous glacial retreat and high levels in closed-basin lakes cannot be explained by glacial melt water, but probably reflects higher snowlines and more precipitation. A relatively minor glacial advance, perhaps related to the "Younger Dryas" in Europe, may be penecontemporaneous with a slight transgression in lake levels about 10-11 $\mathrm{ka}$ in the western Basin and Range, suggesting a temporary return to cooler or wetter conditions, or both at the termination of the Pleistocene.
\end{abstract}

\section{Introduction}

The study of terminal lakes in closed basins and glaciations in adjacent ranges in the Basin and Range Province, U.S.A. (Graf, 1987) is more than a century old (Russell, 1885, 1889; Gilbert, 1890; Blackwelder, 1931). Great advances have been made during the last century in determining the timing and paleoclimatic importance of these lake and glacial events, and these have been summarized recently (Porter, 1983; Smith and StreetPerrott, 1983; Currey and Oviatt, 1985a,b; Davis and Osborn, 1987; Benson and Thompson, 1987a,b; Benson et al., 1990). Particularly well defined is the last 40,000 years because it is amenable to radiocarbon dating. There are con- siderable uncertainties, however, about when some closed-basin lakes started regressions from highstands and when glacial maxima occurred, due to the paucity of datable material.

A method of radiocarbon dating organic matter from rock varnishes by using accelerator mass spectrometry (AMS) is discussed in this paper. This method provides minimum ages for the exposure of a rock surface at sites where suitable material for conventional radiocarbon dating often is lacking. Rock varnish is a coating of predominantly manganese and iron oxides and clay minerals, and has more than 30 minor trace elements, including carbon. Varnish starts to form on stable rock surfaces in deserts about $60-100$ years after exposure (Whitley and Dorn, 1987; 
Dorn et al., 1988). Varnish forms by the manganese- and iron-oxidizing activity of bacteria that concentrate these oxides (Dorn and Oberlander, 1981, 1982; Krumbein and Jens, 1981; Palmer et al., 1985); subsequent clay cementation traps ambient trace and minor elements into the matrix of clays and oxides. In environments that are sufficiently alkaline to inhibit dissolution of varnish by acidifying agents, varnish accumulates as a synsedimentary deposit. By extracting organic detritus incorporated in and buried under the lowest layer of the varnish, the exposure age of the underlying rock can be determined. Tests of AMS radiocarbon dating of rock varnish are presented here for sites where conventional radiocarbon ages are known.

The purpose of this paper is to present and discuss new varnish radiocarbon ages for shoreline and glacial sites in the western Basin and Range Province (Fig.1) where material for conventional radiocarbon dating has been lacking. Although in dispute (Winograd et al., 1988), the timing of global ice fluctuations has been established by the marine $\delta^{18} \mathrm{O}$ record (Shackleton and Opdyke, 1973; Imbrie and Imbrie, 1980). Martinson et al. (1987) have developed a high-resolution chronostratigraphy for global ice fluctuations, reflecting mainly continental ice sheets. Comparatively little is known about when mountain glaciers in the Basin and Range Province, U.S.A. reached their maximum extent and when glacial recessions occurred (Porter et al., 1983). More is known about the response of closed-basin lakes in the Basin and Range (Benson et al., 1990), but some uncertainties exist as to when the highstands were last abandoned. The issue explored here is a comparison of the timing of glacial and lake events in the western Basin and Range Province, U.S.A. (Graf, 1987). This is accomplished by reviewing available data and presenting new varnish radiocarbon ages. These data have important implications for interpretation of the latest-Pleistocene paleoclimate in the region.

\section{Methods}

Manganese-rich black rock varnish is collected from stable clasts. Boulders more than $1 \mathrm{~m}$ in

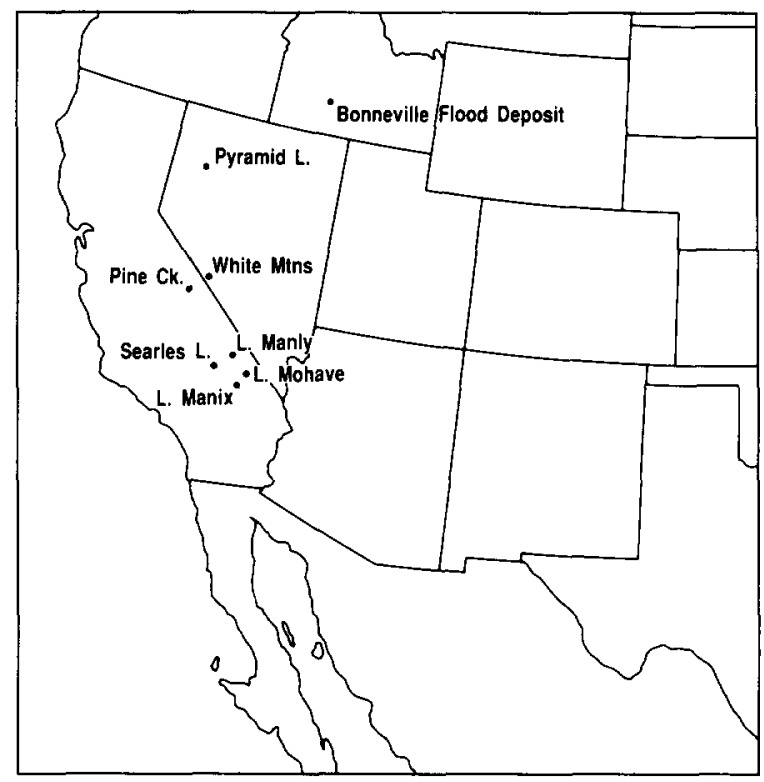

Fig. 1. Location of sampling sites.

diameter are preferred. Due to small concentrations of organic matter in the varnish, often less than $1 \%$ by weight, sometimes as much as $1 \mathrm{~m}^{2}$ of varnish needs to be collected. Lithologies that are unstable, such as granitic rocks that undergo granular disintegration, are avoided. Sites that have mechanical abrasion from aeolian or fluvial processes and sites that are acidic (e.g., from microcolonial fungi or lichens) are not sampled. Rocks that have endolithic organisms and lithologies like smooth quartz that promote a timetransgressive growth of varnish (Dorn and Oberlander, 1982) are not collected.

After collection, the samples are processed in the laboratory. They first are sorted into 10 groups of equal surface area. Random chips are broken and examined by using scanning electron microscopy (SEM). Average varnish depth and variability in depth is characterized. If the sample has abundant microcolonial fungi, filamentous fungi, cyanobacteria, or lichens (Fig.2), it is rejected. A texture like Fig.3a indicates continuous deposition and if continuous would be appropriate for dating. Next, all but the bottom $10 \%$ of the varnish is removed by scraping, with a tungsten-carbide needle under $10-45 \mathrm{x}$ magnification. The depth of removal is tested by using SEM analysis of randomly selected 
pieces obtained throughout the scraping process (Fig.3). Then, the bottom layer of the varnish is removed completely. A sample of similar volume is collected from the rock underlying the varnish to assess whether carbon is present in the underlying rock that might contaminate the radiocarbon age.

The basal layer of the varnish (and the control rock sample) is processed to concentrate the stable organic matter in the basal layer. All processing is done in the fume hood. The steps for concentrating the stable organic matter follow:

(a) The sample is treated, using $35-38 \% \mathrm{HCl}$, and is digested for 3-45 mins to remove inorganic carbonate detritus that could affect the radiocarbon analysis. The sample is washed thoroughly in deionized water.

(b) The sample is equilibrated, using concentrated HF $(52-55 \%)$ for $<1-36 \mathrm{~h}$, depending on the length of time needed for digestion. Longer times usually are required for the control sample of the underlying rock to remove silicates. The samples are washed thoroughly in deionized water.

(c) The varnish sample is dispersed in deionized water and $4-5 \%$ sodium dithionite is added. The mixture is digested for $30-50 \mathrm{~min}$ in a $40^{\circ} \mathrm{C}$ water bath. The procedure may be repeated 1-2 more times. The sample is then washed thoroughly in deionized water. This is similar to the process described by Deb (1950).

(d) The sample then is equilibrated, using $0.3 \mathrm{M}$ hydroxylamine hydrochloride (adjusted to $\mathrm{pH}$ 2) for 15-90 min. The supernatant is decanted and the sample is washed thoroughly in deionized water. This step may be repeated. It is similar to the procedure used by Chao (1972).

(e) Detectable levels of organic matter in the control samples of the underlying rock are unusual. If organic matter is found, however, the varnish sample from the site is not suitable for radiocarbon dating because contamination from the underlying rock could affect the AMS radiocarbon analysis by providing older carbon. A more suitable lithology is selected when the site is resampled. In addition, a scraping procedure is used where the underlying rock material is not removed (Dorn et al., 1987). The radiocarbon dating of varnish organic matter is by AMS (Jull et al., 1986; Linick et al., 1986).

Table 1 presents tests of ${ }^{14} \mathrm{C}$ dating of rock varnish where conventional radiocarbon ages are available for lava flows on the arid and semiarid western slope of Hualalai Volcano, Hawaii. Hualalai has been the subject of detailed mapping (Moore et al., 1987) and radiocarbon dating of charcoal buried beneath the lava flows (Rubin et al., 1987). Varnish radiocarbon ages in Table 1 are slightly younger than the subflow charcoal; this is due mostly to dated organics in varnish coming from a bottom layer that has deposited over a period of time. The lag between the varnish and conventional ${ }^{14} \mathrm{C}$ age is greater for older samples, because the bottom $10 \%$ of the varnish represents a longer period of accretion for older samples. Tests have been conducted to assess possible errors associated with: different individuals who scrape varnishes from the same site; different sample collection methods; different AMS laboratories analyzing duplicate samples; different ways of chemically processing the varnish; possible contamination from older carbon sources; how closed different components of varnish are to exchange with sources of younger carbon; and other possible uncertainties. A discussion of these results is beyond the scope of this paper, but these tests are presented in detail in Dorn et al. (1989). When these variables are controlled, a statistically significant relationship is found between the AMS varnish ${ }^{14} \mathrm{C}$ age and the conventional ${ }^{14} \mathrm{C}$ age of subflow charcoal beneath the same lava flows on the desert rainshadow side of Hualalai Volcano, Hawaii (Fig.4).

Shorelines at the Silver Lake arm of Lake Mojave (Fig.1; Ore and Warren, 1971; Wells et al., 1987) were the site of tests of radiocarbon dating of varnish of the effect of biogeochemical erosion and the possibility of dating orange varnish. Microcolonial fungi (Staley et al., 1982) can influence a varnish radiocarbon age because it erodes pits into varnishes (Fig.2) and younger varnish refills these pits (Fig.2C,D). After sampling varnishes that have dense growths of microcolonial fungi (observed at the surface and in thin section with SEM), the basal layer of the varnish on the highest shoreline, shoreline A (Wells et al., 1987) yielded a radiocarbon age of $4320 \pm 105$ yr B.P. (AA-2133). This age is much younger than either the suite of conventional radiocarbon ages from 11 to $15 \mathrm{ka}$ (Ore and Warren, 1971; Wells et al., 1987) or the 

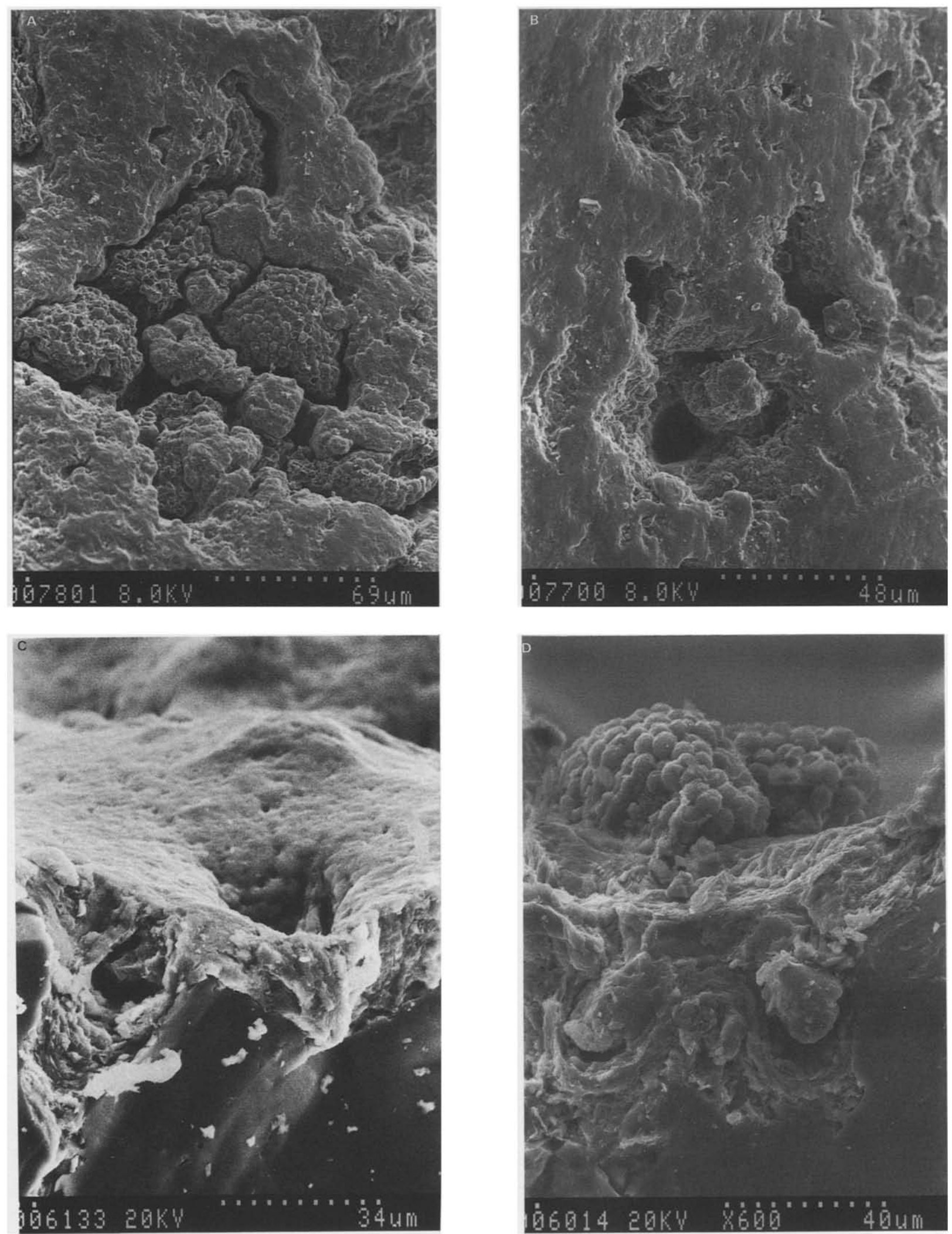
TABLE I

Comparison of ${ }^{14} \mathrm{C}$ ages of varnish and subflow charcoal from the same lava flow, Hualalai Volcano, Hawaii (Moore et al., 1987). Charcoal radiocarbon ages from Rubin et al. (1987)

\begin{tabular}{lccl}
\hline Flow & Charcoal ${ }^{14} \mathrm{C}$ & Varnish ${ }^{14} \mathrm{C}$ (Lab no) & Comments \\
\hline Waha Pele & $710 \pm 150$ & $605 \pm 70$ (AA-2137) & Xeric site; little vegetation \\
Puu Anahulu & $2030 \pm 80$ & $1910 \pm 50$ (AA-2018) & Wrapped in plastic after collected \\
& & $1955 \pm 90($ AA-2132) & Wrapped in aluminium foil \\
& & $1895 \pm 50$ (AA-2322) & Prepared by D. L. Tanner \\
8001 ft Cone & $2670 \pm 80$ & $2470 \pm 65$ (AA-2012) & Sample to Arizona Accelerator \\
& & $2450 \pm 100$ (Beta 17865) & Sample to Zurich (ETH 2480) \\
Puu Waawaa & $3030 \pm 200$ & $2565 \pm 55$ (AA-2016) & Xeric site, little vegetation \\
& & $2550 \pm 80$ (AA-2013) & Grassland biome \\
6360 Hualalai & $6360 \pm 100$ & $5220 \pm 80$ (AA-2134) & Grassland biome \\
Summit & $8770 \pm 200$ & $7215 \pm 85$ (AA-2128) & Buried by ash after exposure \\
Keopu Flow & $12,950 \pm 150$ & $11,755 \pm 295$ (Beta 17864; ETH 2479). \\
\hline
\end{tabular}

carefully sampled varnish age of $11,630 \pm 150 \mathrm{yr}$ B.P. (AA-2319).

Orange varnish is similar to classic black varnish, except it lacks an enrichment of manganese more than ambient levels (Dorn and Oberlander, 1982). It is similar in that it is composed of iron oxides, clay minerals and trace elements. However, the details of its genesis and development are not well understood (Dorn and Oberlander, 1982). The undersides of cobbles in a desert pavement and the crevices of rocks that collect desert dust are common sites of its occurrence. An attempt was made to extract organic matter from the basal layer of extremely well-developed bottom orange varnish from the second highest shoreline at Silver Lake, shoreline B (Wells et al., 1987). The AMS radiocarbon age is $8675 \pm 80$ yr B.P. (AA2015), which is within $2 \sigma$ overlap with the $9060 \pm 160$ yr B.P. (AA-1299) basal age for black varnish from the same cobbles on shoreline $B$. The advantage of orange varnish, if it can be used reliably as a material to extract radiocarbon datable material, is that it occurs on the undersides of cobbles in desert pavements in sites of active aeolian abrasion. The black varnish, which is exposed to the atmosphere, is abraded easily; the orange varnish on the underside of the cobble is protected from abrasion. The difficulty in using bottom orange varnish is its development is not well understood.

Shackleton et al. $(1988$, p. 710$)$ reported that radiocarbon ages around the time of deglaciation could be affected by ventilation of the deep oceans. They concluded in: "conventional ${ }^{14} \mathrm{C}$ terms, the ${ }^{14} \mathrm{C}$ activity of the atmosphere dropped by $100 \%$ [per mil] within $3000 \mathrm{yr}$ or less, perceptibly compressing the radiocarbon time scale of events in this critical interval of time." Almost all of the radiocarbon ages discussed in this paper could be affected by the role of deep-ocean ventilation on the radiocarbon timescale. Therefore, the results reported in this paper, and those from the period

Fig.2. Scanning electron microscope (SEM) images of biogeochemical erosion of varnish. These features should be avoided in varnishradiocarbon dating. The total length of the scale dots is indicated by the scale on the lower right.

A. Microcolonia fungi that are actively eroding a pit into vanish at Crater Flat, southern Nevada.

B. Bioetch pits in which microcolonial fungi, cyanobacteria or lichen no longer are growing; from Crater Flat, southern Nevada.

C. Cross section of unoccupied bioetch pits, Death Valley, California. The left one has been filled in by younger varnish; the right one has not, which indicates development of the pits at different times.

D. Cross section of filled-in bioetch pit, Death Valley, California, and microcolonial fungi that are starting to grow again at the surface at the same microsite. 

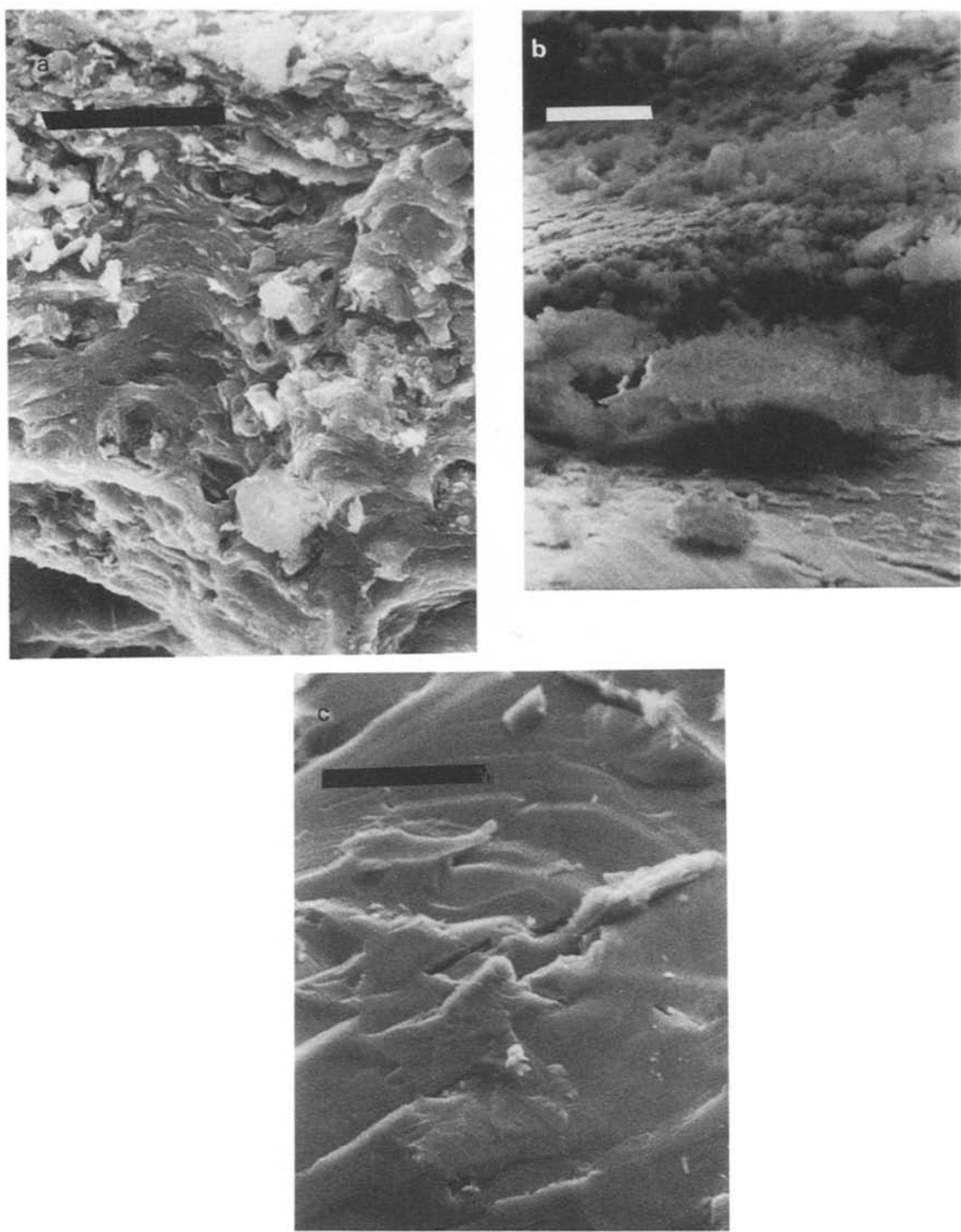

3. SEM images of varnish scraped to the bottom layer for radiocarbon dating. Sample is from Puu Waawaa, Hualalai (see Table ge $a$ is unscraped varnish; $b$ is varnish that is scraped to the lowest layer; $c$ is the underlying rock when the varnish is removed. Ba 10,5 and $25 \mu \mathrm{m}$, respectively.

deglaciation, must be considered preliminary, il the complete effect of deglaciation ventilation setter understood.

\section{sults of radiocarbon dating of varnish from sed-basin lakes}

ke Bonneville

The latest-Pleistocene cycle of Lake Bonneville i some of best age determination of any closed- basin in the Basin and Range Province (Currey ar Oviatt, 1985a,b; Currey and Burr, 1988). TI Bonneville Flood (Malde, 1968) released the upp $104 \mathrm{~m}$ of Lake Bonneville into the Snake River in period that extended from 2 months to 1 ye: (Jarrett and Malde, 1987). Consistent radiocarbc data indicate the flood occurred arour $14,500 \pm 300$ yr B.P. (Currey and Burr, 1988). deposit from this flood, the Melon Gravel, w: collected near Hagerman, Idaho. (Figs.1 and : Organic matter in the basal layer of varnish $c$ 


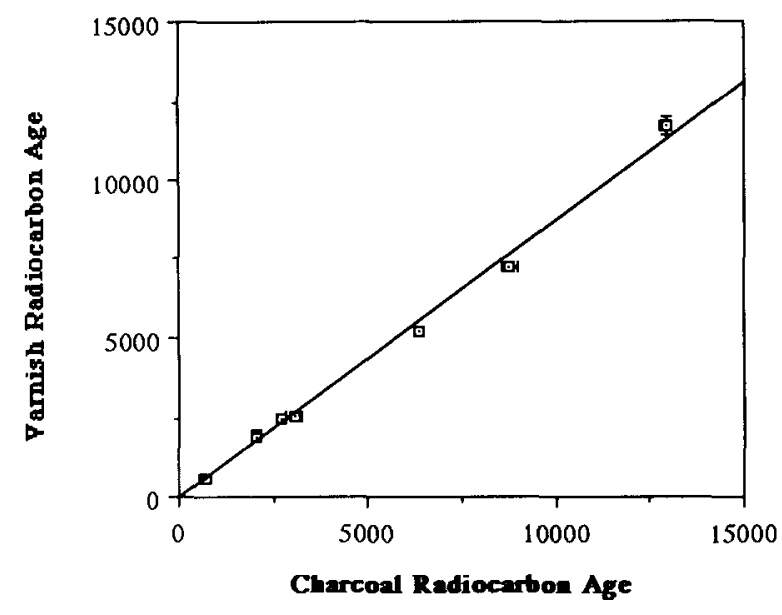

Fig.4. Comparison of ${ }^{14} \mathrm{C}$ ages for varnish and subflow charcoal from the same lava flows on the semiarid side of Hualalai Volcano, Hawaii (Moore et al., 1987). ${ }^{14} \mathrm{C}$ ages listed are in Table 1 and the conventional charcoal dating is described in detail by Rubin et al. (1987). Counting errors are usually less than symbol boxes, so some errors are not displayed. The line is a least-squares regression of: Varnish ${ }^{14} \mathrm{C}$ age $=14.0+0.87$ (Charcoal ${ }^{14} \mathrm{C}$ age) and the relationship is significant at $p=0.001$.

boulders more than several meters in diameter yielded an age of $14,050 \pm 130 \mathrm{yr}$ B.P. (AA-2316). Because the varnish radiocarbon age is from organic matter that is incorporated into the manganese and iron oxides and detritus soon after exposure of the rock by the subsiding flood, the varnish age is consistent with the established age.

\section{Lake Lahontan}

The latest cycle of Lake Lahontan has been studied most recently by Davis (1982) and Benson and Thompson $(1987 \mathrm{a}, \mathrm{b})$. Benson and Thompson (1987a) indicated that the $1330 \mathrm{~m}$ high shoreline was abandoned sometime before the $12,350 \pm 180$ yr B.P. age on Juniperus at $1240 \mathrm{~m}$ from Crypt Cave. Lithoid tufa at 1332 and $1330 \mathrm{~m}$ yields ages of $13.3 \pm 0.2 \mathrm{ka}, 13.3 \pm 0.02 \mathrm{ka}, 13.34 \pm 0.2 \mathrm{ka}$, and $12.85 \pm 0.6 \mathrm{ka}$. Hawley and Wilson (1965) reported ${ }^{14} \mathrm{C}$ ages for Anodonta shells in the basin at $1332 \mathrm{~m}$, $1323 \mathrm{~m}$, and $1318 \mathrm{~m}$ of $13,200 \pm 400,12,700 \pm 400$, and $13,350 \pm 400 \mathrm{yr}$ B.P., respectively; all are within one sigma overlap. Organic matter in basal varnish from the high terrace at the northern end of Pyramid Lake (Figs.1,6) yielded a minimumlimiting age of $12,680 \pm 105$ yr B.P. (AA-2319). The varnish radiocarbon age is about 500 years younger than that of the tufa and Anodonta shells found near the highstand at about $1330 \mathrm{~m}$ and about 300 years older than woody material found at $1240 \mathrm{~m}$.

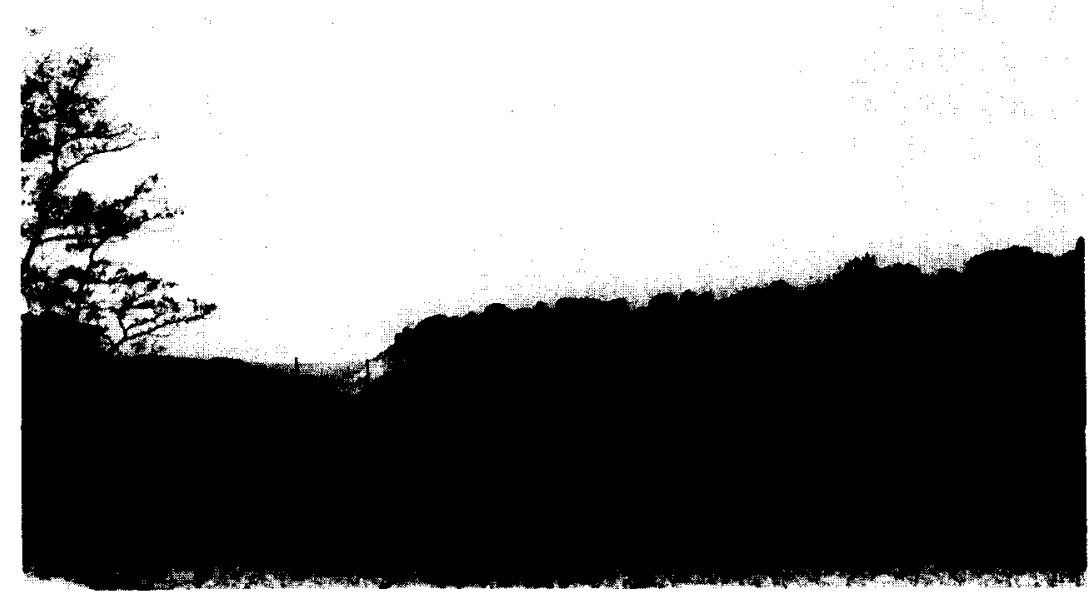

Fig.5. Large boulders on terrace are Bonneville Flood gravels, near Hagerman, Idaho. Note house and telephone pole below the terrace for scale. 


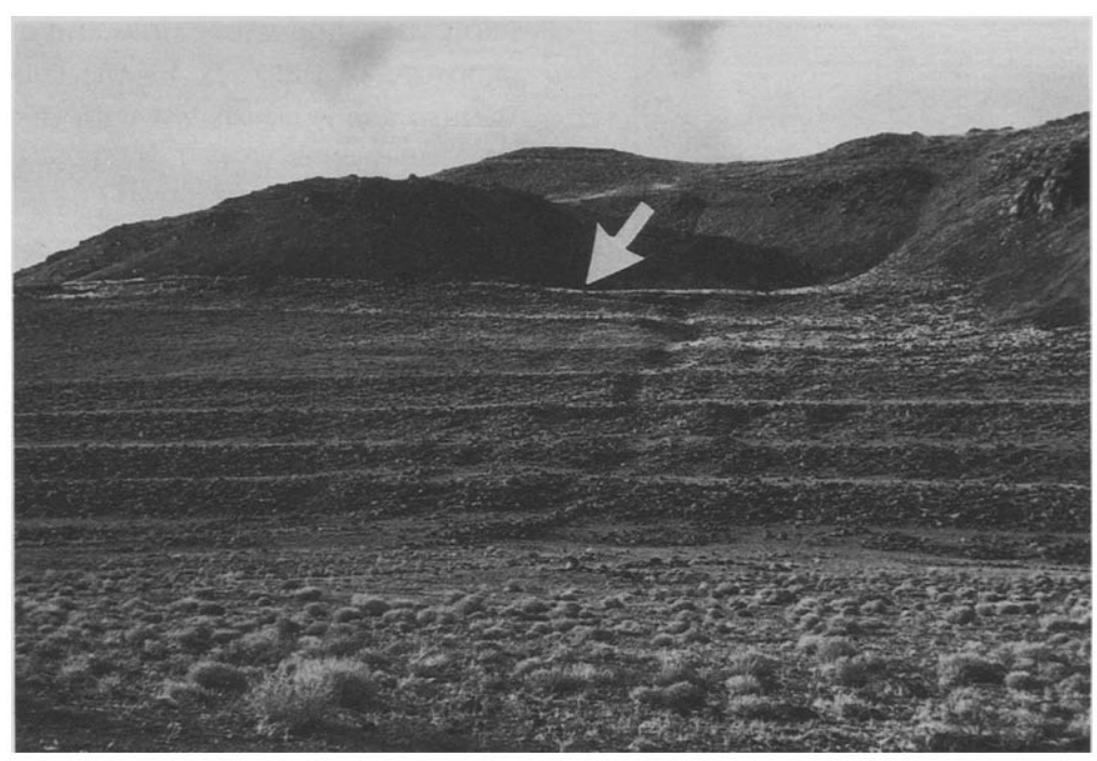

Fig.6. Shorelines of Lake Lahontan at the north end of Pyramid Lake. The varnish from the highstand at about $1330 \mathrm{~m}$ (collected at arrow) yielded a radiocarbon age of $12,680 \pm 105 \mathrm{yr}$ B.P.

The varnish radiocarbon age is quite consistent with the conventional ages, but the counting errors of the tufa, shell and varnish ages makes them indistinguishable. It is virtually impossible that enough varnish formed to date a lower layer that represents the precise timing of the fall of the lake. It is more likely that the tufa ages are minimum estimates for the recession of the last highstand, as tufa is easily contaminated by secondary carbonbearing material (L. V. Benson, pers. comm., 1988). For example, tufa sample PL 103 for $1321 \mathrm{~m}$ yields a radiocarbon age of $12,540 \pm 190$ (Benson and Thompson, 1987a). The varnish radiocarbon age is also a minimum-age as the dated material did form after the lake regression exposed the cobbles to varnishing.

It is likely that some organic matter that was dated could have been deposited on a rock before the onset of varnishing; organic matter attached to the rock would likely have been incorporated as the varnish oxides precipitated. G. I. Smith (pers. comm., 1988) suggested that organic matter from lake algae could have been deposited on rocks as the lake level dropped, and that this algae could have already been radiocarbon "old" while growing because of the delay in equilibrating lake $\mathrm{CO}_{2}$ with atmospheric $\mathrm{CO}_{2}$. This source of contami- nation is possible, but no algal structures have been observed in varnish cross sections using SEM. G. I. Smith (pers. comm., 1988) noted, however, while that algal structures might not be preserved some of this carbon could have still been incorporated into the varnish.

It is unlikely that any older varnish carbon from a previous lake highstand would have contaminated this varnish age, as there is no thin section evidence to indicate the presence of uneroded varnish. In addition, when the current shorelines of Pyramid Lake or Walker Lake are examined, all previous varnish has been eroded by contemporary littoral processes. The interpretation favored here is that the Juniperus wood, the tufa, the Anodonta shells, and the varnish are all minimum-ages for the last regression from the $1330 \mathrm{~m}$ highstand.

\section{Searles Lake}

Smith (1976, 1979, 1984; Smith and StreetPerrott, 1983) reported Searles Lake (Fig.1) last had high water until about $10.5 \mathrm{ka}$, according to interpretations of core records. Tufa ${ }^{14} \mathrm{C}$ ages for the highstand are scattered widely and are often stratigraphically reversed, suggesting that the minimum and maximum ages for a particular unit are 


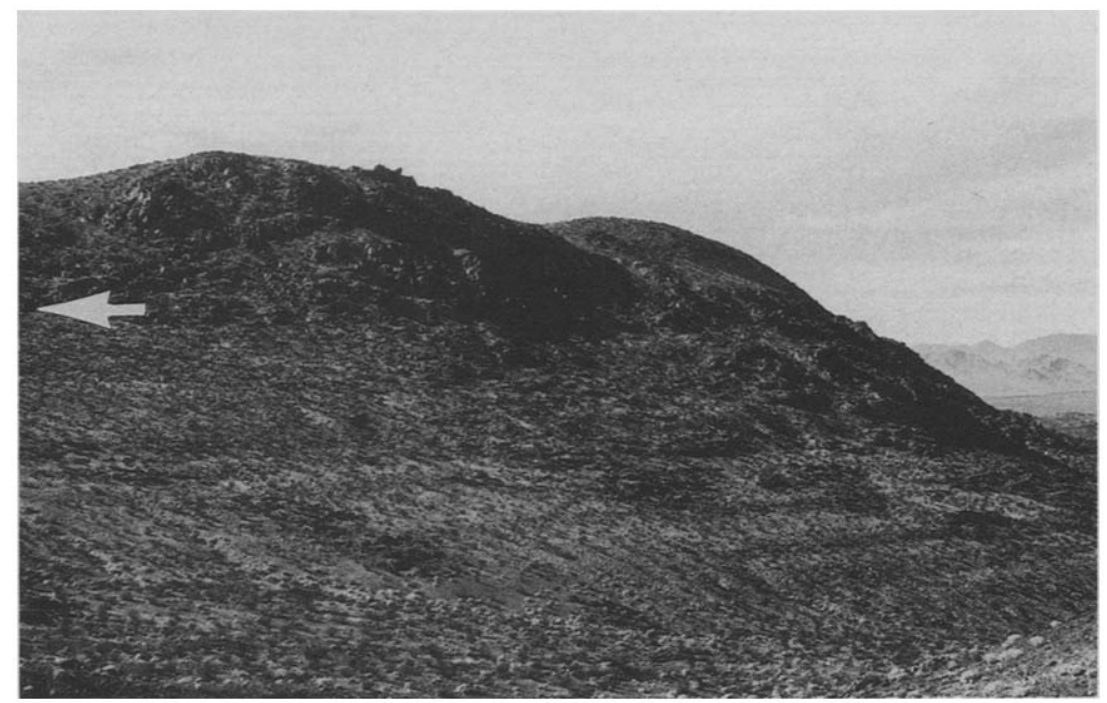

Fig.7. Shorelines of Searles Lake near Poison Canyon. Varnish was collected from the high, overflow stand, just to the left of the arrow at the upper left of the photo.

probably inappropriate indicators of the start or end of a highstand (Benson et al., 1990). An alternative approach might be to use the average of a suite of 22 radiocarbon ages on nodose tufa, oolites, organics and mollusks from outcrops that correlate with the last overflow highstand. The average is $12.8 \pm 1.1 \mathrm{ka}$ (G. I. Smith, pers. comm., 1988).

Rock varnish that was collected from the overflow highstand at Poison Canyon on the western side of Searles Lake (Fig.7) and at Gold Bottom Mine on the eastern side yielded radiocarbon ages of 13,610 $\pm 110 \quad(\mathrm{AA}-2229)$ and $13,290 \pm 115$ yr B.P. (AA-2230), respectively. These radiocarbon varnish ages are interpreted to be minimum-limiting ages for the exposure of the wave-abraded rocks at the highstand. Contamination from older sources of carbon is considered unlikely. Sources of older carbon from the underlying rock have been detected and eliminated in sampling. No thin section evidence indicates varnish was preserved from an earlier lake cycle. Contamination from the incorporation of lake algae is possible, but as in the case of the Lake Lahontan shorelines, no prominent algal structures were seen in cross sections. The interpretation favored here is that the varnish radiocarbon ages and the outcrop radiocarbon ages are minimum estimates for the last regression of the overflow highstand that probably occurred before $13.6 \mathrm{ka}$. However, Smith $(1976,1979,1984)$ does demonstrate that a later lake re-established and lasted until about $10.5 \mathrm{ka}$. Whether it was an overflow event is questionable. If the lake was at the overflow position at $10.5 \mathrm{ka}$, the varnish would have been eroded and the varnish clock would have been reset.

\section{Lake Manly}

Hooke (1972) presented the first radiocarbon ages for Lake Manly (Fig.1), Death Valley, California, by radiocarbon dating sediment from short cores of playa sediment. The latest cycle of Pleistocene Lake Manly started before about $26 \mathrm{ka}$ and lasted until just before $10 \mathrm{ka}$. Humics that were 8-9 $\mathrm{m}$ deep yielded a ${ }^{14} \mathrm{C}$ age of $12,980 \pm 700$ yr B.P. A sample from $13.2-14.0 \mathrm{~m}$ in another core with a higher rate of sedimentation yielded an age of $11,900 \pm 200 \mathrm{yr}$ B.P.

The next issue is to determine which shorelines are associated with this cycle of lacustrine sedimentation. The shoreline sequences in Death Valley are best observed at Mormon Point (Fig.8) and at Shoreline Butte, but they can also be seen at scattered locations throughout the Valley (Hooke, 


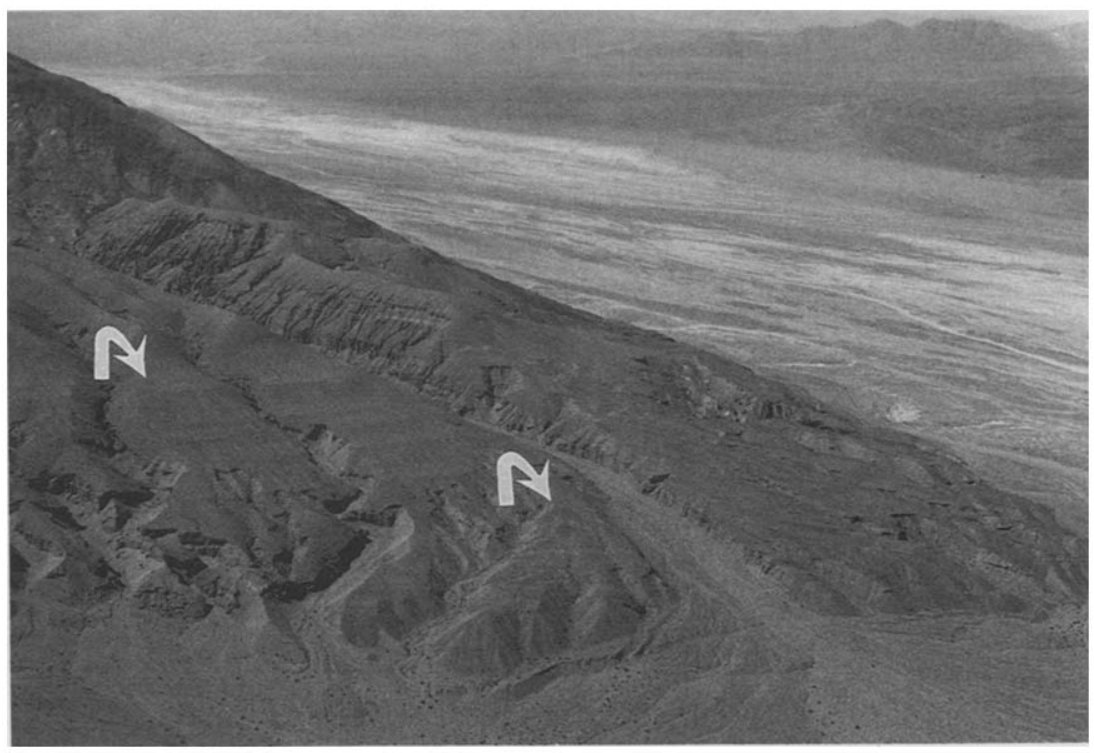

Fig.8. Shorelines of Lake Manly at Mormon Point, Death Valley, California. Upper arrow indicates high shoreline about $88 \mathrm{~m}$ abandoned about 120-130 ka (Dorn, 1988). Lower arrow indicates location of a beach ridge of the latest lake cycle; the varnish on the beach ridge yields a radiocarbon age of $12,970 \pm 185$.

1972). Blackwelder (1933) felt that the prominent high shorelines at Mormon Point (upper arrow in Fig.8) and Shoreline Butte were not produced by the most recent high stand of Lake Manly, but rather by an earlier lake cycle. Hooke (1972) first believed that the "Blackwelder" highstand, at about $87 \mathrm{~m}$ on Shoreline Butte, was associated with the radiocarbon ages in the cores (Hooke, 1972). Subsequent uranium-series analyses on tufa, however, led Hooke and Lively (1979) to conclude that the "Blackwelder" stand was actually associated with a lake dating from 225 to $135 \mathrm{ka}$. Cationratio dating (cf. Dorn, 1989; Dorn et al., 1989) of varnish on the "Blackwelder" shoreline indicated that abandonment occurred about 120-130 ka (Dorn, 1988). This is consistent with Hooke and Lively's (1979) analyses. Thus the Blackwelder stand probably ended near the close of marine oxygen-isotope stage 6 (cf. Shackleton and Opdyke, 1973; Imbrie and Imbrie, 1980; Martinson et al., 1987).

New cation-ratio and radiocarbon ages indicate that the latest-Pleistocene high stand of Lake Manly occupied shorelines at about sea level. Radiocarbon dating of varnish on cobbles on a small beach ridge at about $+3 \mathrm{~m}$ at Mormon Point (lower arrow in Fig.8) indicates that the recession started before $12,970 \pm 185$ yr B.P. (ETH 2409; Beta 17172). A shoreline at about $-5 \mathrm{~m} 1 / 4 \mathrm{~km}$ northwest of the Park Service Housing has a varnish radiocarbon age of $12,630 \pm 1100 \mathrm{yr}$ B.P. (AA-1299). These dates suggest that the latest cycle of Lake Manly started its decline before $13 \mathrm{ka}$. That the best-developed shorelines in Death Valley are from an early like cycle is attributed to the fact that it lasted longer (Hooke and Lively, 1979) and that it was twice as deep, as Blackwelder (1933) originally thought.

\section{Lake Manix}

Meek (1989) has reexamined the lake-level history of Pleistocene Lake Manix (Fig.1), in the central Mojave Desert, California. Lake Manix failed because of a hydrologic flood that lowered the level of the lake outlet rapidly through the outlet that is now Afton Canyon. Meek (1989) presents an age of $14,230 \pm 1325$ yr B.P. for Anodonta shells resting just below the top of a beach ridge that crests at $543 \mathrm{~m}(1780 \mathrm{ft})$. An AMS radiocarbon age of varnish from this same beach ridge is $13,970 \pm 120$ yr B.P. (AA-2317). The Anodonta and varnish ages 
are interpreted here as minimum ages for the hydrologic failure of Lake Manix.

\section{Lake Mojave}

Lake Mojave (Fig.1) is the present-day terminus of the Mojave River that heads in the San Bernardino Mountains in southeastern California. The northern arm of Lake Mojave, Silver Lake, has been studied extensively and has radiocarbon ages on tufa, Anodonta shells, and organic matter in drill core material (Ore and Warren, 1971; Wells et al., 1987; Enzel et al., 1988). Wells et al. (1987) designated the two highest shorelines as $\mathbf{A}$ and $\mathbf{B}$. Varnish radiocarbon analyses from shoreline A indicate that it was last abandoned as a site of wave action sometime before $11,630 \pm 150 \mathrm{yr}$ B.P. (AA2319), and that shoreline $B$ was abandoned before $9060 \pm 160$ yr B.P. (AA-1299). The varnish age for shoreline A, however, may only indicate storm wave erosion during the occupation of shoreline $B$, because $B$ is only a few meters below $A$. The published radiocarbon ages for tufa and shell do not completely limit the last regression events, but these varnish radiocarbon ages are consistent with current interpretations of published dates and with newer radiocarbon measurements from organics in drill core material (Enzel et al., 1988).

\section{Varnish radiocarbon dating of Late Pleistocene glacial recessions in the Basin and Range Province}

Glaciers were present in the Basin and Range Province, as testified by moraines extending out of the Sierra Nevada into the Owens Valley, California, on the western end and moraines debouching from the Wasatch Range, Utah on the eastern end. The timing of the maximum extent of latest Pleistocene glaciers in the Basin and Range are now only being determined. Several intervening mountain ranges have been studied using numerical age control (Wayne, 1984; Currey et al., 1986; Elliott-Fisk, 1987).

In the Sierra Nevada, four sources of radiocarbon ages are available on the Tioga glaciation (Blackwelder, 1931). Adam (1967) reported a minimum age for deglaciation in the Lake Tahoe area of about $10 \mathrm{ka}$. Atwater et al. (1986) indicated that the Tioga glaciation in the western Sierra Nevada started about $26 \mathrm{ka}$. Mezger and Burbank (1986) obtained radiocarbon ages of 10.6, 10.3 and $10.1 \mathrm{ka}$ for basal bog material formed behind the latest Wisconsin moraine in the southeastern Sierra Nevada, but they do not state whether they analyzed till from the Tioga glaciation or from a post-Tioga "Younger Dryas" event. Dorn et al. (1987) used varnish radiocarbon dating to indicate the maximum Tioga glaciation occurred before about $19 \mathrm{ka}$ at Pine Creek, near Bishop, California (Fig.1). Recession of the Pine Creek glacier into the canyon occurred just before about $13 \mathrm{ka}$. Phillips et al. (1990) determined the maximum extent of the Tioga glaciation occurred around $20 \mathrm{ka}$ at Bloody Canyon entering the Mono Basin, California, using the build-up of chlorine-36 in exposed rocks.

Elliott-Fisk (1987) presented a new chronology for the glacial geomorphology of the White Mountains, California-Nevada, just to the east of the Sierra Nevada (Fig.1). The White Mountains have probably the longest exposed record of glacial events in the Basin and Range, and perhaps in North America (Elliott-Fisk, 1987). The latest Wisconsin event, the Middle Creek glaciation, has been dated in the Middle Creek drainage and in Chiatovich Canyon. Varnish radiocarbon ages of $18,510 \pm 250$ yr B.P. (ETH 2414; Beta 17177) and $12,710 \pm 240$ yr B.P. (ETH 2483; Beta 17868) are minimum ages for the maximum advance and the last recession in Middle Creek. In the Chiatovich drainage, the maximum advance and last recession occurred before $17,780 \pm 400$ yr B.P. (ETH 3201; Beta 22215) and 12,510 \pm 270 yr B.P. (ETH 3194; $22208)$, respectively. The varnish radiocarbon ages from the Chiatovich drainage are consistent with preliminary chlorine-36 measurements (Phillips et al., 1990). These data indicate glaciations in the different valleys were penecontemporaneous in the White Mountains. The Middle Creek glaciation in the White Mountains also appears to be penecontemporaneous with the Tioga glaciation in the Sierra Nevada at Pine Creek (Dorn et al., 1987) and at Bloody Canyon (Phillips et al., 1990). A younger glaciation was present in the Chiatovich cirque. The varnish radiocarbon age for the minimum age on this event is $9740 \pm 210 \mathrm{yr}$ B.P. (ETH 3200; Beta 22214). This event might corre- 
late with the latest-Wisconsin event in the Cottonwood Lakes area of the Sierra Nevada, which was radiocarbon dated by Mezger and Burbank (1986) to be before $10.1-10.6 \mathrm{ka}$.

Scott (1988) presented data about the age of the maximum extent of the Bells Canyon glaciation at Little Cottonwood Canyon and Bells Canyon, Wasatch Range, Utah. The age for the till that extends out of the range is younger than the radiocarbon age of $26 \mathrm{ka}$ for soil material that is below the till. A thin, partly eroded soil is present on the till, but it was buried by transgressive sediments of the Lake Bonneville cycle that date about 16-16.5 ka (Currey and Oviatt, 1985a,b). The soil on the till and below the Lake Bonneville sediments is inferred to represent about 2000 years of soil development (cf. Scott, 1988). Therefore, the maximum glacial advance occurred about 18-20 ka (Scott, 1988). Madsen and Currey (1979) indicated the glaciers in Little Cottonwood Canyon had retreated past a mid-canyon position by $14-13 \mathrm{ka}$.

In the Basin and Range numerical ages also exist for glaciations in the Ruby Range, Nevada, and Markagunt Plateau, Utah. Wayne (1984) indicates complete deglaciation of the Ruby Range before about 13.0 $\pm 0.9 \mathrm{ka}$. Currey et al. (1986) obtained radiocarbon ages to indicate deglaciation in the Markagunt Plateau started well before $14.4 \pm 0.85$ ka.

\section{Paleoclimatic implications}

By limiting the timing of regressions of closedbasin lakes and of glacial events in the surrounding ranges, insights into paleoclimatic events can be obtained. Only Mono Lake and Lake Bonneville have glacial deposits and lake shorelines that occupied the same site. In both places, high lakes stands post date the glacial moraines of the Sierra Nevada (Gilbert, 1890; Lajoie and Robinson, 1982) and of the Wasatch Range (Antevs, 1952; Scott, 1988).

Lajoie and Robinson (1982) indicated three periods of high lake levels at Mono Lake which extended from 36 to $34 \mathrm{ka}, 28$ to $24 \mathrm{ka}$ and lastly from 14 to $12 \mathrm{ka}$. A reevaluation of the ${ }^{14} \mathrm{C}$ data led Benson et al. (1990) to a revision that the last high stand may have occurred from 15 to $14 \mathrm{ka}$, with prior intermediate or high levels from 35 to 17 ka. The 35-17 period would correspond with the Tioga maximum about $19-20 \mathrm{ka}$, which was dated by the varnish radiocarbon method at Pine Creek (Dorn et al., 1987) and ${ }^{36} \mathrm{Cl}$ at Bloody Canyon (Phillips et al., 1990). The last highstand, whether from 14 to $12 \mathrm{ka}$ or from 15 to $14 \mathrm{ka}$, does not correlate with the last Sierran glacial maximum. Scott (1988) reported that this lag also occurred between the maximum glaciation of the Wasatch Range (about 20-19 ka) and of Lakes BonnevilleProvo (16.5-14 ka).

The maximum extent of oxygen-isotope stage 2 glaciers (Shackleton and Opdyke, 1973; Imbrie and Imbrie, 1980) in the Basin and Range seems to have been about $20-18 \mathrm{ka}$ in the eastern Sierra Nevada, western Wasatch Range, and the White Mountains. A major part of the recession of these glaciers occurred by about 13-14 ka for the Tioga glacier at Pine Creek in the Sierra Nevada, California, before about 12-13 for glaciers in the White Mountains, California-Nevada, by about 13-14 in the Wasatch Range, Utah, by about $13 \mathrm{ka}$ in the Ruby Range, Nevada, and well before 14-15 $\mathrm{ka}$ in the Markagunt Plateau, Utah.

As the glaciers in the Basin and Range were receding, the closed-basin lakes were rising to their highstands, about $16.5 \mathrm{ka}$ for Lake Bonneville, about $15 \mathrm{ka}$ for Lake Lahontan, about $15 \mathrm{ka}$ for Lake Russell, and about $14 \mathrm{ka}$ for Lake Manix. Searles Lake may have been high when the glaciers were at their maximum (Smith and Street-Perrott, 1983). Lake Manly remained at its latest Pleistocene high stands until about $13 \mathrm{ka}$. More southern lakes in the Basin and Range seem to have lasted, perhaps, until $12 \mathrm{ka}$ at Lake Mojave and at Lake Estancia, New Mexico (Smith and Anderson, 1982).

Gilbert (1890) demonstrated that the melting of glaciers would not have provided enough water to produce high stands in the lake basins. An increase in precipitation had to occur to offset the warming responsible for glacial ablation and permit high lake levels, as Lajoie and Robinson (1982), Smith and Anderson (1982), and Benson and Thompson (1987) have all observed. Spaulding and Graumlich (1986) and Davis (1986) have suggested an increase in warm season monsoon precipitation to 
account for vegetation patterns in the southern Nevada area at the close of the Pleistocene. However, Benson and Klieforth (1989) reported that recharge in southern Nevada during the latest Pleistocene did not have a signal of abundant monsoon precipitation, as determined by oxygenisotope analyses. Benson and Thompson (1987b) also doubted an increase in monsoon flow during this time, because summer monsoons would have been less effective than frontal precipitation in maintaining high levels of the closed-basin lakes. [Of note, Van Devender et al. (1987) questioned some of Spaulding and Graumlich's (1986) interpretations.] Benson and Thompson (1987b) and Kutzbach (1987) suggested a southward shift and intensification of the warm season jet stream to account for a surge of late-Pleistocene frontal moisture. Unfortunately, the spatial distribution of lake basins examined here is not adequate to test this hypothesis.

The paleoclimatic interpretations presented by Spaulding and Graumlich (1986) and Davis (1986) based on the vegetation record and by Benson and Klieforth (1989) based on isotopic groundwater data need to be reconciled. The abundance of monsoonrelated plants observed by Spaulding and Graumlich (1986) to occur at the close of the Pleistocene indicates a lack of freezing conditions. Benson and Thompson's (1987) interpretations and Benson and Klieforth (1989) isotopic data do not indicate summer monsoon precipitation. One possible reconciliation is that frontal storms did supply the precipitation during the cool season, but under a synoptic type with little freezing and high snowlines. This might explain both the isotopic and the macrofossil evidence. An important constraint on paleoclimatic interpretations imposed by the varnish data presented in this paper is that snowlines would have had to have been much higher, or an increase in frontal precipitation would have caused another glacial advance. Models of synoptic types related to major freezing events and of synoptic types related to high snowlines, for areas where the macrofossil record indicates an increase in warm-season precipitation in the latest Pleistocene, may prove useful in resolving differences in interpretation.

A terminal Pleistocene glacial event, perhaps equivalent to the "Younger Dryas" climatic in
Europe, may have occurred about $10-11 \mathrm{ka}$ in the western Great Basin. Chiatovich cirque is the highest cirque in the White Mountains; a small glacial moraine formed after $13 \mathrm{ka}$ and was abandoned before $9740 \pm 210$ (ETH 3200; Beta 22214). In the Cottonwood Lakes area of the Sierra Nevada, the latest Pleistocene deglaciation occurred by about 10.1-10.6 ka (Mezger and Burbank, 1986). Similarly, "Temple Lake" moraines in the Rocky Mountains, once interpreted to be Holocene, probably represent a last Pleistocene glaciation that may date to about $12 \mathrm{ka}$ (Davis and Osborn, 1987).

This terminal Pleistocene glacial event may be roughly synchronous with stands of closed-basin lakes in the Basin and Range. Currey and Oviatt (1985a,b; Currey and Burr, 1988) note the occurrence of a terminal-Pleistocene Lake Gilbert shoreline complex about $10-11 \mathrm{ka}$ for the Bonneville basin. Smith $(1976,1979,1984)$ reported a transgression of Searles Lake that ended around $10.5 \mathrm{ka}$. Thompson (1984) reported that Lake Franklin had a slight transgression to a level just above modern levels before $9.8 \pm 0.4 \mathrm{ka}$. Benson et al. (1990) believe this relatively minor oscillation in lake level may be associated with the "Younger Dryas".

The more southern paleolakes in the Basin and Range seem to have had later highstands than closed-basin lakes to the north, but at least one occurred before the terminal-Pleistocene event. Ore and Warren (1971), Wells et al. (1987) and the varnish radiocarbon ages reported here indicate that Lake Mojave was high about $12 \mathrm{ka}$ and again around $9 \mathrm{ka}$. Significantly, Lake Mojave was high after Lake Manix hydrologically failed upstream (Meek, 1989). The Mojave River and Lake Mojave would have been hydrologically tied to the southern California transverse ranges after about $14 \mathrm{ka}$. Lake Estancia was high until about $12 \mathrm{ka}$ (Smith and Anderson, 1986). However, marshes in southern Nevada gradually declined from about 14 to $7.2 \mathrm{ka}$ (Quade, 1986).

Numerical age control is minimum for this potential "Younger Dryas" event. The intensity of this latest Pleistocene glacial and lake event was much less than the glacial maximum that occurred about $20-18 \mathrm{ka}$ and lake highstands that occurred 
about 16-12 ka. However, the paleoclimatic implications are distinct. If the glaciers and lakes were synchronous, a relatively short intensification of cooler conditions and/or more winter season precipitation would be implied. This event may have to be reconciled temporally and/or dynamically with the paleoecological interpretations of Davis (1986) and Spaulding and Graumlich (1986) indicating an intensification of monsoonal flow, probably after the palaeolakes started regressions from their highstands.

\section{Summary}

AMS radiocarbon dates of organic matter extracted from the basal layer of rock varnish are close minimum-limiting ages for the exposure of the rock underlying the varnish. This is demonstrated by comparing varnish AMS ${ }^{14} \mathrm{C}$ ages with conventional ${ }^{14} \mathrm{C}$ ages of subflow charcoal beneath lava flows of Hualalai Volcano, Hawaii.

Radiocarbon dating of rock varnish has been applied to the highstands of closed-basin lakes in the western Basin and Range Province, USA. Lake Bonneville and Lake Manix failed from hydrologic floods before 14,050 $\pm 130 \mathrm{yr}$ B.P. and 13,970 \pm 120 yr B.P., respectively. Lake Lahontan, Searles Lake, Lake Manly and Lake Mojave started regressions due to climatic causes before $12,680 \pm 105$, $13,610 \pm 110,12,970 \pm 185$, and $11,630 \pm 150 \mathrm{yr}$ B.P., respectively.

${ }^{14} \mathrm{C}$ ages for rock varnishes on glacial moraines provide the first surface exposure ages for the maximum of the Tioga glaciation in the Sierra Nevada, California and the White Mountains, California-Nevada. The maxima occurred before 19-18 ka, similar to the Wasatch Range, Utah, placed at 20-18 ka by Scott (1988). Glaciers from these ranges underwent major recessions by 13-12 $\mathrm{ka}$, but they readvanced in the Sierra Nevada and White Mountains about 10-11 ka.

Several paleoclimatic interpretations are possible for these data. The maximum advances in the Sierra Nevada, White Mountains and Wasatch Range appear to coincide with the continental glacial record (cf. Martinson et al., 1987). The highstands of closed-basin lakes in the western Basin and Range occurred about 16-12 ka and lagged behind the glacial maximum by about $3000-8000{ }^{14} \mathrm{C}$ years. However, this lag will probably be less after correction for the deepocean ventilation effect on ${ }^{14} \mathrm{C}$ age (Shackleton et al., 1988).

As Lajoie and Robinson (1982) and others have observed, the highstands of closed-basin lakes in the Basin and Range required an increase in precipitation. Snowlines also had to have been much higher during the highstands of these lakes, because glaciers in the Basin and Range were receding at the same time. Following Spaulding and Graumlich (1986) and Davis (1986) who examined the paleobiogeographic record, Dorn et al. (1987) argued that an increase in warm-season precipitation would explain penecontemporaneous glacial recessions and high lake stands. An increase in warm-season precipitation is inconsistent with Benson and Klieforth's (1989) ground water isotope data. A possible reconciliation would be an increase of frontal winter storms that had high snowlines and minimal frosts.

The data presented here are consistent with a cold and dry climate in the northern Great Basin during the glacial maxima (cf. Brakenridge, 1978; McCoy, 1981, 1987). This condition gave way to a warmer and wetter climate from 16.5 to $12 \mathrm{ka}$, depending on the location in the Basin and Range. Data are not sufficient to reconstruct the spatial pattern of this transition, nor are they sufficient to assess the seasonal nature of the precipitation increase. After a regional desiccation that took place about 14-12 ka, depending on location, there is growing body of data that a relatively small terminal Pleistocene glacial advance and lake level rise may have occurred in the Basin and Range about 10-11 ka.

\section{Acknowledgements}

The research for this paper was funded mostly by NSF SES86-01937 and NSF Presidential Young Investigator Award to Dorn. The Death Valley work was funded by National Geographic Society grant 84-2961. Thanks to L. V. Benson, D. Dorn, D. Elliot-Fisk, R. LeB. Hooke, N. Meek, R. B. Moore, M. Rubin, G. I. Smith, J. Stipp, T. Swanson, M. Tamers, D. L. Tanner, F. Trusdell, 
S. G. Wells, W. Wolfli, and for field and lab assistance, lab analyses and comments. Thanks to B. Trapido for graphics assistance.

\section{References}

Adam, D. P., 1967. Late-Pleistocene and recent palynology in the Sierra Nevada, California. In: E. I. Cushing and H. E. Wright, Jr. (Editors), Quaternary Palynology. Yale Univ. Press, New Haven, Conn., pp. 275-301.

Antevs, E., 1952. Cenozoic climates of the Great Basin. Geol. Rundsch., 40: 94-108.

Atwater, B. F., Adam, D. P., Bradbury, J. P., Forester, R. M., Mark, R. K., Lettis, W. R., Fisher, G. R., Gobalet, K. W. and Robinson, S. W., 1986. A fan dam for Tulare Lake, California, and implications for the Wisconsin glacial history of the Sierra Nevada. Geol. Soc. Am. Bull., 97: 97-109.

Benson, L. V. and Klieforth, H., 1989. Stable isotopes - in precipitation and ground water in the Yucca Mountain region, southern Nevada: Paleoclimatic implications. In: Interdisciplinary Aspects of Climate Variability in the Pacific and western Americas. Am. Geophys. Union, Washington, D.C., in press.

Benson, L. V., Currey, D. R., Dorn, R. I., Lajoie, K. R., Oviatt, C. G., Robinsin, S. W., Smith, G. I., Stine, S. and Thompson, R. S., 1990. Variation in sizes of four Great Basin lake systems during the past 35,000 years. Palaeogeogr., Palaeoclim., Palaeoecol., 78: 000 000.

Benson, L. V. and Thompson, R. S., 1987a. Lake-level variation in the Lahontan Basin for the past 50,000 years. Quat. Res., 28: 69-85.

Benson, L. V. and Thompson, R. S., 1987b. The physical record of lakes in the Great Basin. In: W. F. Ruddiman and H. E. Wright, Jr. (Editors), North America and Adjacent Oceans During the Last Deglaciation (Geology of North America, K-3). Geol. Soc. Am., Boulder, Colo. pp. 241-260.

Blackwelder, E., 1931. Pleistocene glaciation in the Sierra Nevada and Basin Ranges. Geol. Soc. Am. Bull., 42: 865-922.

Blackwelder, E., 1933. Lake Manly, an extinct lake in Death Valley. Geogr. Rev., 23: 464-471.

Brakenridge, G. R., 1978. Evidence for a cold, dry full-glacial climate in the American Southwest. Quat. Res., 9: 22-40.

Chao, T. T., 1972. Selective dissolution of manganese oxides from soils and sediment with acidified hydroxylamine hydrochloride. Proc. Soil Sci. Soc. Am., 36: 764-768.

Currey, D. R. and Burr, T. N., 1988. Linear model of thresholdcontrolled shorelines of Lake Bonneville. In: M. Machette (Editor), In the steps of G. K. Gilbert, Lake Bonneville and Neotectonics, Eastern Basin and Range. Utah Geol. Min. Surv. Misc. Publ., 88-1: 104-110.

Currey, D. R. and Oviatt, C. G., 1985a. Durations, average rates, and probable causes of Lake Bonneville expansion, still-stands, and contractions during the last deep-lake cycle 32,000 to 10,000 years ago. In: P. A. Kay (Editor), Problems and Prospects for Predicting Great Salt Lake levels. Center for Public Affairs and Administration, Univ. Utah, Salt Lake City, pp. 9-24.

Currey, D. R. and Oviatt, C. G., 1985b. Durations, average rates and probable causes of Lake Bonneville expansions, still stands, and contractions during the last deep-lake cycle 32,000 to 10,000 years ago. Geogr. J. Korea, 10: 1085-1099.

Currey, D. R., Mulvey, W. E. and Lindsay, L. W., 1986. Markagunt Plateau, Utah: Southern margin of late Wisconsinan glaciation in the Great Basin. Am. Quat. Assoc. Progr. Abstracts, p. 126.

Davis, J. O., 1982. Bits and pieces: the last 35,000 years in the Lahontan area. In: D. B. Madsen and J. F. O'Connell (Editors), Man and Environment in the Great Basin. Soc. Am. Archaeol. Pap., 2: 53-75.

Davis, O. K., 1986. A late glacial pluvial maximum, the history of the Arizona monsoon and the astronomical theory of climatic change. Am. Quat. Assoc. Progr. Abstracts, p. 127.

Davis, P. T. and Osborn, G., 1987. Age of pre-Neoglacial cirque moraines in the central North American Cordillera. Geogr. Phys. Quat., 41: 365-375.

Deb, B. C., 1950. The estimation of free iron oxides in soils and clays and their removal. J. Soil Sci., 1: 212-220.

Dorn, R. I., 1986. Rock varnish as an indicator of aeolian environmental change. In: W. G. Nickling (Editor), Aolian Geomorphology. Allen and Unwin, London, pp. 291-307.

Dorn, R. I., 1988. A rock varnish interpretation of alluvial-fan development in Death Valley, California. Natl. Geogr. Res., 4: $56-73$

Dorn, R. I., 1989. Cation-ratio dating: a geographic perspective. Prog. Phys. Geogr., 13: 559-596.

Dorn, R. I. and DeNiro, M. J., 1986. Stable carbon isotope ratios of rock varnish organic matter: A new paleoenvironmental indicator. Science, 227: 1472-1474.

Dorn, R. I. and Oberlander, T. M., 1981. Microbial origin of desert varnish. Science, 213: 1245-1247.

Dorn, R. I. and Oberlander, T. M., 1982. Rock varnish. Prog. Phys. Geogr., 6: 317-367.

Dorn, R. I., Bamforth, D. B., Cahill, T. A., Dohrenwend, J. C., Turrin, B. D., Donahue, D. J., Jull, A. J. T., Long, A., Macko, M. E., Weil, E. B., Whitley, D. S. and Zabel, T. H., 1986. Cation-ratio and accelerator-radiocarbon dating of rock varnish on Mojave artifacts and landforms in the Mojave Desert, eastern California. Science, 231: 830-833.

Dorn, R. I., DeNiro, M. J. and Ajie, H. O., 1987. Isotopic evidence for climatic influence on alluvial fan development in Death Valley, California. Geology, 15: 108-110.

Dorn, R. I., Turrin, B. D., Jull, A. J. T., Linick, T. W. and Donahue, D. J., 1987. Radiocarbon and cation-ratio ages for rock varnish on Tioga and Tahoe morainal boulders of Pine Creek, eastern Sierra Nevada, California, and their paleoclimatic implications. Quat. Res., 28: 38-49.

Dorn, R. I., Nobbs, M. and Cahill, T. A., 1988. Cation-ratio dating of rock engravings from the Olary Province of arid South Australia. Antiquity, 62: 681-689.

Dorn, R. 1., Jull, A. J. T., Donahue, D. J. Linick, T. W. and Toolin, L. J., 1989. AMS radiocarbon dating of rock varnish. Geol. Soc. Am. Bull., 101: 1363-1376

Elliott-Fisk, D. L., 1987. Glacial geomorphology of the White Mountains, California and Nevada: Establishment of a glacial chronology. Phys. Geogr., 8: 299-323.

Enzel, Y., Brown, W. J., Anderson, R. Y. and Wells, S. G., 1988. Late Pleistocene-early Holocene lake stand events recorded in cored lake deposits and in shore features, Silver 
Lake playa, eastern Mojave Desert, southern California. Geol. Soc. Am. Abstr. Progr., 20: 158.

Gilbert, G. K., 1890. Lake Bonneville. U.S. Geol. Surv. Monogr., 1, $438 \mathrm{pp}$.

Graf, W. L., 1987. Regional geomorphology of North America. In: W. L. Graf (Editor), Geomorphic Systems of North America (Centennial Special, 2). Geol. Soc. Am., Boulder, Colo., pp. 1-4.

Hawley, J. W. and Wilson, W. E., III., 1965. Quaternary geology of the Winnemucca area, Nevada. Desert Res. Inst. Tech. Rep., 5, 33 pp.

Hooke, R. L., 1972. Geomorphic evidence for late Wisconsin and Holocene tectonic deformation, Death Valley, California. Geol. Soc. Am. Bull., 83: 2073-2098.

Hooke, R. L. and Lively, R. S., 1979. Dating of Quaternary deposits and associated tectonic events by U/Th methods, Death Valley, California. Final Report for NSF Grant EAR 79-19999, Washington, D.C., 21 pp.

Imbrie, J. and Imbrie, J. Z., 1980. Modelling the climatic response to orbital variations. Science, 207: 943-953.

Jarrett, R. D. and Malde, H. E., 1987. Paleodischarge of the late Pleistocene Bonneville Flood, Snake River, Idaho, computed from new evidence. Geol. Soc. Am. Bull., 99: 127-134.

Jull, A. G. T., Donahue, D. J., Hatheway, A. L., Linick, T. W. and Toolin, L. J., 1986. Production of graphite targets by deposition from $\mathrm{CO} / \mathrm{H}_{2}$ for precision accelerator ${ }^{14} \mathrm{C}$ measurements. Radiocarbon, 28: 191-197.

Krumbein, W. E. and Jens, K., 1981. Biogenic rock varnishes of the Negev Desert (Israel): An ecological study of iron and manganese transformation by cyanobacteria and fungi. Oecologia, 50: 25-38.

Kutzbach, J. E., 1987. Model simulations of the climatic patterns during the deglaciation of North America. In: W. F. Ruddiman, H. E. Wright, Jr. (Editors), North America and Adjacent Oceans During the Last Deglaciation (Geology of North America, K-3). Geol. Soc. Am., Boulder, Colo. pp. $425-446$.

Lajoie, K. R. and Robinson, S. W., 1982. Late Quaternary glacio-lacustrine chronology Mono Basin, California. Geol. Soc. Am. Abstr. Progr., 14: 179.

Linick, T. W., Jull, A. J. T., Toolin, L. J. and Donahue, D. J., 1986. Operation of the NSF-Arizona accelerator facility for radioisotope analysis and results from selected collaborative research projects. Radiocarbon, 28: 522-533.

Madsen, D. B. and Currey, D. R., 1979. Late Quaternary glacial and vegetation changes, Little Cottonwood Canyon area, Wasatch Mountains, Utah. Quat. Res., 12: 254-268.

Malde, H. E., 1968. The catastrophic late Pleistocene Bonneville Flood in the Snake River Plain, Idaho. U.S. Geol. Surv. Prof. Pap., 596, 52 pp.

Martinson, D. G., Pisias, N. G., Hayes, J. D., Imbrie, J., Moore, T. C., Jr. and Shackleton, N. J., 1987. Age dating and the orbital theory of the ice ages: development of a highresolution 0 to 300,000-year chronostratigraphy. Quat. Res., 27: 1-29.

McCoy, W. D., 1981. Quaternary aminostratigraphy of the Bonneville and Lahontan basins, western U.S., with paleoclimatic implications. Thesis. Univ. Colorado, Boulder, $603 \mathrm{pp}$.

McCoy, W. D., 1987. Quaternary aminostratigraphy of the
Bonneville basin, western United States. Geol. Soc. Am. Bull., 98: 99-112.

Meek, N., 1989. Geomorphic and hydrologic implications of the rapid incision of Afton Canyon, Mojave Desert, California. Geology, 17: 7-10.

Mezger, L. and Burbank, D., 1986. The glacial history of the Cottonwood Lakes Area, southeastern Sierra Nevada. Geol. Soc. Am. Abstr. Progr., 18: 157.

Moore, R. B., Clague, D., Rubin, M. and Bohrson, W. A., 1987. Hualalai Volcano: A preliminary summary of geologic, petrologic and geophysical data. In: R. W. Decker and P. H. Stauffer (Editors), Volcanism in Hawaii. U.S. Geol. Surv. Prof. Pap., 1350: 571-585.

Ore, H. T. and Warren, C. N., 1971. Late Pleistocene-early Holocene geomorphic history of Lake Mojave, California. Geol. Soc. Am. Bull., 82: 2553-2562.

Palmer, F. E., Staley, J. T., Murray, R. G. E., Counsell, T. and Adams, J. B., 1985. Identification of manganese-oxidizing bacteria from desert varnish. Geomicrob. J., 4: 343-360.

Phillips, F. M., Zreda, M. G., Smith S. S., Elmore, D., Kubik, P. and Sharma, P., 1990. A cosmogenic chlorine-36 chronology for glacial deposits at Bloody Canyon, eastern California. Science, in press.

Porter, S. C., Pierce, K. L. and Hamilton, T. D., 1983. Late Wisconsin mountain glaciation in the western United States. In: S. C. Porter (Editor), The Late Pleistocene. Univ. Minnesota Press, Minneapolis, pp. 71-111.

Quade, J., 1986. Late Quaternary environmental changes in the upper Las Vegas Valley, Nevada. Quat. Res., 26: 340-357.

Rubin, M., Gargulinski, L. and McGeehin, J. P., 1987. Hawaiian Radiocarbon Dates. In: R. W. Decker and P. H. Stauffer (Editors), Volcanism in Hawaii. U.S. Geol. Surv. Prof. Pap., 1350: 213-242.

Russell, I. C., 1885. Geologica; history of Lake Lahontan, a Quaternary lake of northwestern Nevada. U.S. Geol. Surv. Monogr., 11, 287 pp.

Russell, I. C., 1889. Quaternary history of Mono Valley, California. In: Eighth Annu. Rep. U.S. Geol. Surv., 1886-87, Part I. U.S. Geol. Surv. Annu. Rep., 8: 261-394.

Scott, W. E., 1988. Temporal relation of lacustrine and glacial events at Little Cottonwood and Bells Canyons. In: $\mathbf{M}$. Machette (Editor), In the steps of G. K. Gilbert, Lake Bonneville and Neotectonics, Eastern Basin and Range. Utah Geol. Min. Surv. Misc. Publ., 88-1: 78-81.

Shackleton, N. J., Duplessy, J.-C., Arnold, M., Maurice, P., Hall, M. A. and Cartlidge, J., 1988. Radiocarbon age of last glacial Pacific deep water. Nature, 335: 708-711.

Shackleton, N. J. and Opdyke, N. D., 1973. Oxygen isotope and paleomagnetic stratigraphy of equatorial Pacific core V28. 238: Oxygen isotope temperatures and ice volumes on a $10^{5}$ and $10^{6}$ year scale. Quat. Res., 3: 39-55.

Smith, G. I., 1976. Paleoclimatic record in the upper Quaternary sediments of Searles Lake, California, U.S.A. In: S. Horie (Editor), Paleolimnology of Lake Biwa and the Japanese Pleistocene. Kyoto Univ., Kyoto, 4, pp. 577-604.

Smith, G. I., 1984. Paleohydrologic regimes in the southwestern Great Basin, 0-3.2 m.y. ago, compared with other long records of "global" climate. Quat. Res., 22: 1-17.

Smith, G. I., 1979. Subsurface stratigraphy and geochemistry of late Quaternary evaporites, Searles Lake, California, with a 
section on radiocarbon age of stratigraphic units, by $\mathrm{N}$. Stuiver and G. I. Smith. U.S. Geol. Surv. Prof. Pap., 1043, $130 \mathrm{pp}$.

Smith, G. I. and Street-Perrott, F. A., 1983. Pluvial lakes of the western United States. In: S. C. Porter (Editor), The Late Pleistocene. Univ. Minnesota Press, Minneapolis, pp. 190-212.

Smith, L. N. and Anderson R. Y., 1982. Pleistocene-Holocene Climate of the Estancia Basin, central New Mexico. In: J. F. Callender (Editor), Albuquerque Country II, New Mexico Geol. Soc. 33rd Guidebook, pp. 347-350.

Spaulding, W. G., 1985. Vegetation and climates of the last 45,000 years in the vicinity of the Nevada Test Site, southcentral Nevada, U.S. Geol. Surv. Prof. Pap., 1329, 83 pp.

Spaulding, W. G. and Graumlich, L. J., 1986. The last pluvial climatic episodes in the deserts of southwestern North America. Nature, 320: 441-444.

Staley, J. T., Palmer, F. and Adams, J. B., 1982. Microcolonial fungi: common inhabitants on desert rocks? Science, 215: 1093-1095.

Thompson, R. S., 1984. Late Pleistocene and Holocene environments in the Great Basin. Thesis. Univ. Arizona, Tucson, $256 \mathrm{pp}$.

Van Devender, T. R., Thompson, R. S. and Betancourt, J. L., 1987. Vegetation history of the deserts of southwestern North America; the nature and timing of the late Wisconsin-Holocene transition. In: W. F. Ruddiman and H. E. Wright, Jr. (Editors), North America and Adjacent Oceans During the Last Deglaciation (Geology of North America, K-3). Geol. Soc. Am., Boulder, Colo. pp. 323-352.

Wayne, W. J., 1984. Glacial chronology of the Ruby MountainsEast Humboldt Range, Nevada. Quat. Res., 21: 286-303.

Wells, S. G., McFadden, L. D. and Dohrenwend, J. C., 1987. Influence of late Quaternary climatic changes on geomorphic and pedogenic processes on a desert piedmont, eastern Mojave Desert, California. Quat. Res., 27: 130-146.

Whitley, D. S. and Dorn, R. I., 1987. Rock art chronology in eastern California. World Arch., 19: 150-164.

Winograd, I. J., Szabo, B. J., Coplen, T. B. and Riggs, A. C., 1988. A 250,000-year climatic record from Great Basin vein calcite: implications for Milankovitch theory. Science, 242: 1275-1280. 